MONETARY THEORY AND PRACTICE 
Also by C. A. E. Goodhart

Money, Information and Uncertainty

The New York Money Market and the Finance of Trade, 1900-1913

The Business of Banking, 1891-1914 


\section{MONETARY THEORY AND PRACTICE}

\section{The UK Experience}

C. A. E. GOODHART

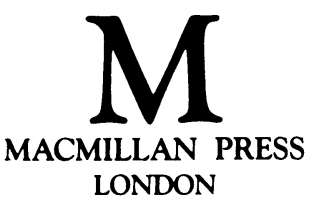


Introduction, Chapters 1-6, 8-10 (C) C. A. E. Goodhart 1970-84

Chapter 1 appendix (C) C. A. E. Goodhart and A. D. Crockett 1970

Chapter 4 appendix 1 (C) C. A. E. Goodhart and T. Shepheard-Walwyn 1979

Chapter 4 appendix 2 (C) C. A. E. Goodhart and A. C. Hotson 1979

Chapter 7 (C) C. A. E. Goodhart, M. D. K. W. Foot and A. C. Hotson 1979

Softcover reprint of the hardcover 1st edition 1984

All rights reserved. No part of this publication may be reproduced or transmitted, in any form or by any means, without permission.

First published 1984 by

THE MACMILLAN PRESS LTD

London and Basingstoke

Companies and representatives

throughout the world

ISBN 978-0-333-36060-6

ISBN 978-1-349-17295-5 (eBook)

DOI $10.1007 / 978-1-349-17295-5$

Typeset in Great Britain by Photo-Graphics, Honiton, Devon 


\section{Contents}

Introduction

1. The Bank's Monetary Specialist

2. The Contents of the Collected Papers

I. The Importance of Money

1. Definition and Function 21

2. The Transmission Mechanism 23

3. The Stability of the Income Velocity of Money 35

4. Conclusions $\quad 42$

Appendix 1: The Evidence of Empirical Investigations 44

Appendix 2: The Demand for Money and Money Multipliers 55

II. Bank of England Studies of the Demand-for-Money Function 67

$\begin{array}{ll}\text { 1. Introduction } & 67\end{array}$

2. Background to the Research $\quad 69$

3. Using Demand-for-Money Relationships as a Policy Guide 74

4. Controlling the Monetary Aggregates 81

5. The Direction of Causation $\quad 85$

6. The Relationship between Research and Policy: A Summary 87

III. Problems of Monetary Management: The UK Experience 91

1. Introduction $\quad 91$

2. Bank Behaviour and the Money Supply 96

3. The Demand for Money 106

4. Policy Response 113

Appendix: Demand-for-Money Equations since 1971

IV. Bank Lending and Monetary Control $\quad 122$

\begin{tabular}{lr} 
1. Introduction & 122 \\
\hline
\end{tabular}

2. Volatility and the Lack of Offsets 123

3. The Difficulty of Forecasting Bank Lending 128

4. Controlling Bank Lending 131

$\begin{array}{ll}\text { 5. Conclusions } & 132\end{array}$

Appendix 1: An Examination of Interest-rate Responsiveness in the
UK and Some Overseas Countries

Appendix 2: The Forecasting and Control of Bank Lending 139

V. Structural Changes in the Banking System and the
Determination of the Stock of Money

$\begin{array}{ll}\text { 1. Introduction } & 146\end{array}$

2. Liability Management $\quad 150$

3. Inflation, Variable-rate Lending and the Importance of the Spread 160

4. Technology and the Retail Depositor 169

5. What can the Central Bank Control? 180 
VI. Analysis of the Determination of the Stock of Money 182

1. Introduction

2. Deficiencies of the Usual Approach

3. The Determination of the Monetary Base 188

4. The Response of the Private Sector 193

$\begin{array}{ll}\text { 5. Conclusion } & 199\end{array}$

VII. Monetary Base Control $\quad 202$

1. Introduction 202

2. The Background 202

3. What is the Monetary Base? 203

4. The Historical Relevance of the Monetary Base in the UK 204

5. Why the Monetary Base may be Relevant 206

6. A Strict Control of Money 209

7. Structural Adjustments in Response to Strict Control 212

8. Some Technical and Operational Changes Required 214

9. More Relaxed Versions of Monetary Base Control 215

10. Summary 218

VIII. Money in an Open Economy 219

$\begin{array}{lr}\text { 1. Introduction } & 219\end{array}$

2. Statistical Identities $\quad 220$

3. Monetary Flows under Pegged Exchange Rates 224

$\begin{array}{ll}\text { 4. Modelling Domestic-External Monetary Flows under the Present } & \\ \text { Exchange-rate Regime } & \end{array}$

IX. The Measurement of Monetary Policy 241

1. Deterministic Models 241

2. Additive Stochastic Uncertainty 244

3. Model Uncertainty 248

X. Disequilibrium Money - A Note $\quad 254$

1. Introduction $\quad 254$

2. The Concept of 'Disequilibrium' 255

3. UK Monetary Experience and 'Disequilibrium' 260

4. Modelling Disequilibrium Money in the Economy 269

$\begin{array}{ll}\text { Index } & 277\end{array}$ 